SECTION 22. Policy. Innovations. Theory, practice and methods.

\author{
Koshechkina Elena Alexandrovna \\ Docent, candidate of historical Sciences, \\ Nevsky Institute of Language and Culture, \\ Saint-Petersburg, Russia
}

\title{
THE REGIONAL POLITICS OF ARMENIA
}

The Southern Caucasus is a region of geopolitical importance. The author analyses politically, economically and culturally significant qualities of the region, due to which it can be called a zone of strategic interests of the main global and regional actors. The article characterizes the model of Armenia's economic development which specificity is caused by close interlacing of geopolitical, internal political and business factors. Special attention is paid to the question of the formation of regional politics of Armenia.

Key words: region, regional integration, regional politics, the South Caucasus, Armenia.

\section{УДК: 332.142}

\section{РЕГИОНАЛЬНАЯ ПОЛИТИКА АРМЕНИИ}

Южный Кавказ рассматривается как регион, имеюший важное геополитическое значение, анализируются политически и экономически значимые качества региона, позволяющие провозгласить его зоной стратегических интересов основных глобальных и региональных акторов. Характеризуется модель экономического развития Армении, специфика которой обусловлена тесным переплетением геополитических, внутриполитических и экономических факторов ее развития. Особое внимание уделено вопросам региональной политики Армении.

Ключевые слова: регион, региональная политика, региональная интеграчия, Южный Кавказ, Армения.

Армения - государство на территории Южного Кавказа, который представляет собой особый геополитический евразийский регион, куда входят также Грузия и Азербайджан. Один из представителей классической геополитической теории К.Хаусхофер выделяет эту территорию, как одну из исторических зон противоборства наравне с Босфором, Гибралтаром, зоной Суэцкого канала и др.[16, с.127]. Южный Кавказ отличается отсутствием стабильности в экономике, 
политике; наличием сильнейших противоречий в международных связях, в первую очередь на региональном уровне, военными конфликтами из-за территорий и по политическим мотивам. По меткому замечанию К.С.Гаджиева здесь «в сложнейший узел переплетены трудно разрешимые социально-экономические, национально-территориальные, конфессиональные, геополитические и иные интересы». [4, с.100] Армения в полной мере в течении последних двадцати с лишним лет ощущает на себе последствия нестабильности и конфликтов в регионе.

Республика Армения (РА) состоит из 11 провинций (Марз, арм. Uup q), разделенных на городские и сельские общины. Губернаторы (марзпеты) назначаются и освобождаются от должности правительством. В общинах осуществляется местное самоуправление. В республике 953 села, 48 городов, 932 общины, из которых 871 сельская и 61 городская.

Несмотря на небольшие размеры страны, регионы Армении отличаются разнообразием, как в природно-климатическом, так и социально-экономическом отношении. По площади территории разрыв составляет 23,6 раза, по численности населения на момент конца первого десятилетия XXI века - около 20 раз, по плотности населения - свыше 200 раз. Например, в целом, численность населения Армении - примерно 3,3 млн., при этом около трети населения государства проживает в столице Ереване.[6] В конце 2011 г. на совещании, посвященному обсуждению Концепции регионального развития Армении вице-премьер, министр территориального управления Армен Геворгян отмечал, что «процесс несоразмерного развития регионов страны углубляется», а премьерминистр Тигран Саргсян отметил, что «сверхцентрализация политических, социальных, экономических культурных возможностей в Ереване препятствует не только естественному развитию столицы, но и общему развитию страны». [12]

Специалисты отмечают, что такие диспропорции появились только после распада единого советского пространства, а до 1991 г. территориальные различия в Армении были минимальны, то есть носили естественный характер. [1,с.50]

Чтобы понять причины диспропорций в региональном развитии, нужно выяснить, в каких условиях оказалась Армения после распада СССР. Как известно, произошел разрыв экономических связей, пронизывавших советское пространство на протяжении нескольких десятилетий. Резкое изменение в политике цен и применение монетаристских методов в экономике привели к разрушению экономически сбалансированной системе хозяйствования. Внутренние источники финансирования были ограничены, зависимость от внешнего инвестирования проявляется до сих пор. Армения - страна не богатая собственными первичными ресурсами, при этом в советское время 
экономика страны была промышленной, ее основой являлись наукоемкие отрасли промышленности - химия, машиностроение, приборостроение, а также предприятия легкой промышленности и цветная металлургия. Находясь в составе СССР, Армения была образцом интегрированности до 90\% всех предприятий республики работали не на местный рынок, но были производствами союзного значения. Сырье и полуфабрикаты поставлялись, в основном, из России, Украины, Белоруссии и Казахстана. Но распад единого советского государства привел к дефициту привозного сырья и, в результате, стагнации промышленных предприятий. Внутренний рынок был слабым, 60\% производимой продукции реализовывалось до 1991 г. за пределами республики. В условиях распада общего экономического пространства такая структура экономики оказалась парализованной. Экспортные возможности Армении были ограничены, что после обретения независимости привело к дефициту валютных поступлений.

Геополитически страна уязвима и зависима от внешних транспортных коммуникаций. А конфликт с близлежащими государствами привел к энергетической и транспортной блокаде: введение Азербайджаном и Турцией санкций против Армении. Турция по соглашению с Азербайджаном закрыла в 1993 году сухопутную границу с Арменией, прекратив транспортное сообщение и экономические связи. Единственным каналом остались регулярные авиарейсы между Стамбулом и Ереваном. А единственной открытой границей (кроме двух небольших участков границы с Ираном на территории Азербайджана) осталась граница с Грузией. Все газо- и нефтепроводы, по которым энергоресурсы поставляются из Азербайджана в Европу, обходят армянскую территорию. В 2006 году Армения протестовала против строительства железной дороги между Азербайджаном и Турцией через территорию Грузии, предлагая пользоваться армянской станцией Гюмри. Дорога Карс-Гюмри остаѐтся недействующей из-за блокады. [17]

Результатом всего вышеперечисленного стал экономический спад ВВП сократился на 70\% (наибольший спад из республик бывшего СССР). В конце 1994 г. ситуация стабилизировалась за счет внешних кредитов, радикального курса реформ, высоких налогов и ограничения и без того низких доходов населения, блокирования реального сектора экономики, сокращения социальной инфраструктуры и др. За период 1994-2010 г. удалось достичь значительного увеличения ВВП - с $\$ 628$ до $\$ 9600$ млн. Соответственно увеличился и ВВП на душу населения - с \$190 до \$ 2885 (в 2008 до \$3606). Малоэффективной оказалась и транспортная блокада. Армения перепрофилировала экономику на производство и переработку малогабаритной продукции (в основном, ювелирной) с низким транспортным коэффициентом. В настоящее время идет строительство автомагистрали "Север-Юг". Этот транспортный коридор призван ослабить блокаду 
Армении со стороны Турции и Азербайджана, нивелировать экономические потери и сделать ее надежной транзитной страной между государствами Восточной Европы и Ираном. В перспективе через Армению налаживание транспортных коммуникаций по маршруту РоссияИран-Индия.

При этом за годы реформ промышленное производство поддерживалось, в первую очередь, в столице. В результате более $50 \%$ производства ВВП приходится на Ереван, что свидетельствует о крайней неравномерности экономического развития Армении (на 10 областей приходится 1.8-9.2\% ВВП). Сельское хозяйство находится в бедственном положении. [3; 4]

По оценкам экспертов, современная ситуация в регионах Армении крайне неблагоприятна: почти половина населения сконцентрирована только в столице, а периферийные и приграничные населенные пункты полупусты. В октябре 2011 г. на первом Форуме сельских общин в городе Джермук премьер-министр Армении Тигран Саркисян заявил, что равномерное развитие регионов крайне актуально для Армении, и эту проблему необходимо решать. По его словам, в стране нужно не только развивать сельское хозяйство, но создавать новые рабочие места на селе, по значению сопоставимые с городскими, в результате чего сельчане не будут вынуждены перебираться в город. [13]

На сегодняшний день Ереван сверхперегружен финансовыми, промышленными, культурными, здравоохранительными, образовательными функциями, а также функциями государственного управления. В связи с чем приоритетными для Армении становятся программы развития областей страны, включая отдаленные территории: от чисто экономических до возрождения традиционных ремесел (ковроткацкого, гончарного, художественной обработке дерева и металла). [8] Среди них: программа стимулирования экспорта в сфере органической сельскохозяйственной продукции, программа по возведению органических садов, программа «Тавуш-2012», которая осуществляется за счет грантов, предоставленных департаментом О-де-Сен Всеармянскому фонду «Айастан» (направлена на улучшение условий жизни населения в приграничных районах и сокращение бедности); программа Экономического подъема при премьер-министре Франции, председателем Генерального совета департамента О-де-Сен Патриком Деведжяном. Другими задачами соразмерного развития областей являются программы дорожного строительства в сельских районах, которые реализуются при содействии международных структур, а также установление противоградовых станций. Особое внимание уделяется развитию сельского туризма. [2] Например, в июле 2013 г. благодаря руководителям Программы развития предприятий и конкурентоспособности рынка (EDMC) Агентства международного развития США и Проекту 
ознакомления с памятниками Армении (АМАР) стартовала двухлетняя международная программа «Черноморский коридор Великого шелкового пути» (BSSRC) при участии представителей Армении, Греции, Турции и Грузии. Она нацелена на стимулирование туризма, трансграничного сотрудничества, развития информационных технологий и инноваций, а также и экономическое развитие 173 общин Армении, Турции, Греции и Грузии и равномерное развитие регионов. Предполагается, что сфера туризма в Армении переживет серьезное развитие, и Программа будет способствовать открытию границ между странами и сближению государств. Посол США в Армении Джон Хефферн отметил, что «сотрудничество протяженностью в 3000 км является очень полезным для четырех стран. Данный проект направлен не только на развитие сферы туризма в странах, но и на восстановление многовековой истории». [10]

Особое внимание с 2006 г. уделяется инфраструктуре в сельских общинах. Фонд социальных инвестиций с 2006 по 2013 г. реализует 263 программы в 148 общинах, из них 28\% направлено на дома культуры и общинные центры в селах, $46 \%$ направлено на развитие специализированных и общеобразовательных школ. [11] C 2011 г. Всемирный банк утвердил предоставление Армении кредита в размере $\$ 16$ млн по программе «Управление и конкурентоспособность сельскохозяйственных ресурсов общин». Предполагалось также реализовать в 2011-2015 гг. «Программу создания сельского потенциала», согласно которой предусматривалось проведение работ по восстановлению общественных инфраструктур (газопроводы, линии питьевой и оросительной воды, сельские дороги).[9]

Необходимость в эффективной региональной политике осознается на всех уровнях политической власти РА. Так, например, в предвыборной программе переизбранного Президента страны Сержа Саргсяна в 2013 г. отдельной строкой проходит цель «Пропорциональное развитие территорий». Он признает и необходимость изменения региональной политики в отношении сельских общин. В частности, выступая перед своими избирателями в январе 2013 г., действующий Президент заявил, что необходимы конкретные программы для повышения жизненного уровня народа, которые не только будут развивать инфраструктуру, но и внедрять новые технологии. При этом традиции армянского народа, безусловно, должны сохраняться. Лозунгом его выступления было: «симметричное развитие регионов - императив для Армении». [14]

Специалистами отмечается, что региональную политику, в частности выравнивание различий в региональном развитии тормозит отсутствие общей концепции. Единого документа, целью которого являлось бы региональное развитие страны не существует. Несмотря на то, что в Армении есть Министерство территориального управления. Оно было создано в 2005 г., но еще в 1995 г. Указом Президента РА был назначен министр по территориальному управлению. Название должности 
изменялось 7 раз, с 2007 г. на министра территориального управления РА возложены обязанности вице-премьер-министра РА. Министерство экономики РА также занимается региональной политикой, в частности, в перечень приоритетных задач входит региональное развитие, а именно преодоление возникших диспропорций в уровнях экономического развития регионов Армении, повышение эффективности сельского хозяйства, создание несельскохозяйственных рабочих мест, повышения уровня занятости населения и т. д. [7]

На сегодняшний день развитие национальной экономики, с одной стороны, способствует региональному развитию, в том числе накапливая финансовые средства для реализации региональной политики, а с другой усугубляет асимметрию в уровнях развития регионов. По мнению зав. кафедрой экономической теории и политики Российской академии народного хозяйства и государственной службы при президенте РФ (РАНХиГС) Абела Аганбегяна, ВВП Армении можно существенно поднять в течение 10 лет за счет развития десяти кластеров экономики: сфера информационных технологий, химическое производство, энергетика, медно-молибденовое производство, аграрно-промышленный комплекс, ювелирная промышленность, жилищное и социальное строительство, транспортная система, туризм и малый бизнес. При это академик подчеркивает, что развитие большинства этих кластеров должно иметь место не в Ереване, а за его пределами, чтобы выправить разницу между развитием столицы и регионов. Ибо диспропорции в развитии регионов страны достигли максимума, и это ключевая проблема развития экономики. [15]

Подводя итоги, можно сказать, что региональная политика в Армении - область непростых решений, и дело ближайшего будущего. Проблема необходимости сбалансированного развития областей страны осознается на самом высшем уровне власти. Программы, реализованные и реализуемые на сегодняшний день в регионах, безусловно, нацелены на выравнивание и поддержание экономического, социального и культурного развития сельских территорий. При этом необходимость создания единой концепции региональной политики в стране является насущной проблемой, решение которой назрело за последние годы. В противном случае прогнозируется угроза подрыва экономической и социальной стабильности общества. Еще одной насущной задачей представляется налаживание прочных экономических связей с близлежащими государствами, в первую очередь, восстановление транспортного коридора - разрушенной железной дороги, которая шла по берегу Черного моря, соединяя Сочи, Абхазию, Западную Грузию и Армению. Это сулит колоссальные выгоды для всего Южного Кавказа. Необходимо также развивать возможности для ведения политического диалога в регионе, 
выработать на совместной основе с помощью или участием международных сил или ведущих государств меры доверия, которые положат конец войнам, конфликтам, спорам и претензиям.

\section{Литература:}

1. Аракелян А.Л. О необходимости проведения политики выравнивания диспропорций регионального развития в Армении //Вопросы современной науки и практики. Университет им. В.И. Вернадского. N1(7). 2007 .

2. Араратян В. Соразмерное территориальное развитие в центре внимания правительства Армении //Информационно-аналитический центр ANALITIKA.at.ua [Электронный pecypc]. - Режим доступа: http://analitika.at.ua/news/sorazmernoe_territorialnoe_razvitie_v_centre_vnimanij a_pravitelstva_armenii/2010-05-31-27413 (дата обращения: $\overline{31}$-05.2010).

3. Вермишев $\bar{M}$. Экономическое развитие Армении за 20 лет. Итоги и перспективы //Научное общество кавказоведов [Электронный ресурс]. Режим доступа: http://www.kavkazoved.info/authors/mihail-vermishev.html (дата обращения: 28.02.2011)

4. Восканян М. Евразийская интеграция - шанс для развития экономики Армении? //Газета армян России «Еркрамас» [Электронный ресурс]. Режим доступа: http://www.yerkramas.org/2012/10/23 (дата обращения: 23.10.2012)

5. Гаджиев К. С. Геополитика Кавказа: М.: Международные отношения, 2003

6. Национальная статистическая служба Республики Армения [Электронный ресурс]. - Режим доступа:

http://www.armstat.am/arm/Publications/2007/sv_12 html (дата обращения: 23.12.2007)

7. Официальный сайт Министерства экономического развития Республики Армения [Электронный ресурс]. - Режим доступа: http://www.mineconomy.am (дата обращения 23.01.2012)

8. Погосян А. О проблемах развития традиционной культуры и об улучшении демографической картины в областях Республики Армения // Национальная идея. 2011. № 9.

9. Поливная вода вырастает в политический фактор // Голос Армении (общественно-политическая газета)[Электронный ресурс]. - Режим доступа: http://www.golosarmenii.am (дата обращения: 24.03.2011)

10.Программа «Черноморский коридор Великого шелкового пути» официально стартовала в Армении//Новости-Армения: агентство международной информации [Электронный ресурс]. - Режим доступа: http://newsarmenia.ru/economy/20130716/42906971.html (дата обращения: 16.07.2013)

11.Программы, касающиеся развития инфраструктуры во всех общинах 
Армении, будут продолжаться //Независимое информационное агентство «Armenia-news.ru» [Электронный pecypc]. - Режим доступа: http://armenianews.ru/03/programmy-kasayushhiesya-razvitiya-infrastruktury-vo-vsexobshhinax-armenii-budut-prodolzhatsya/ (дата обращения: 22.03.2013)

12.Процесс несоразмерного развития регионов Армении углубляется [Электронный pecypc] //Новости Армении. - Режим доступа http://www.gisher.ru/process-nesorazmernogo-razvitiya-regionov-armeniiuglublyaetsya-t23707.html (дата обращения: 23.03.2011)

13. Равномерное развитие регионов крайне актуально для Армении [Электронный ресурс] //Новости Армении. - Режим доступа: http://www.gisher.ru/ravnomernoe-razvitie-regionov-krayne-aktualno-dlyaarmenii-t30741.html (дата обращения: 12.10.2011)

14. Симметричное развитие регионов — императив для Армении //Новости Армении [Электронный ресурс]. - Режим доступа: http://news.am/rus/news/137899.html (дата обращения: 29.01.2013)

15. Сирунян Л. Экономика растет, но жизнь не улучшается // Газета армян России «Еркрамас» [Электронный ресурс]. - Режим доступа: http://www.yerkramas.org/2013/05/05/ekonomika-rastet-no-zhizn-neuluchshaetsya/ (дата обращения: 5.05.2013)

16.Хаусхофер К. Границы в их географическом и политическом значении. // О геополитике. Работы разных лет. М.: Мысль, 2001.

17.Якубян В. Южный Кавказ скатывается к кризису //Regnum информационное агенство [Электронный ресурс]. - Режим доступа: www.regnum.ru/news/531077.html (дата обращения: 19.10.2005) 